\title{
Article
}

\section{Photocatalytic removal of nitric oxide by multi-walled carbon nanotubes-supported $\mathrm{TiO}_{2}$}

\author{
Hao Liu a, Hairu Zhang b, Hongmin Yanga,* \\ a School of Energy and Mechanical Engineering, Nanjing Normal University, Nanjing 210042, Jiangsu, China \\ b Design Institute of Nanjing Shengnuo Heat Pipe Co., Ltd, Nanjing 210009, Jiangsu, China
}

\section{A R T I C L E I N F}

\section{Article history:}

Received 21 July 2013

Accepted 5 September 2013

Published 20 January 2014

\section{Keywords:}

Multi-walled carbon nanotube

Titanium dioxide

Photocatalysis

Denitration

Flue gas

\begin{abstract}
A B S T R A C T
Multi-walled carbon nanotubes (MWCNTs) coated with $\mathrm{TiO}_{2}$ were prepared by a sol-gel method and characterized by transmission electron microscopy, X-ray photoelectron spectroscopy, X-ray diffraction, and UV-Vis diffuse reflectance spectroscopy. It was found that $\mathrm{MWCNTs} / \mathrm{TiO}_{2}$ consisted mainly of anatase phase. The introduction of MWCNTs inhibited $\mathrm{TiO}_{2}$ grain growth. Moreover, the adsorption edge of MWCNTs/ $\mathrm{TiO}_{2}$ shifted toward long-wavelength region compared with bare $\mathrm{TiO}_{2}$. The photocatalytic ability of $\mathrm{MWCNTs} / \mathrm{TiO}_{2}$ for NO removal was experimentally investigated in a fixed-bed reactor. The results showed that a lower initial NO concentration was conducive to NO removal. A negative effect of $\mathrm{SO}_{2}$ on denitration was observed. In contrast, $\mathrm{O}_{2}$ and $\mathrm{H}_{2} \mathrm{O}$ played a promotional role in the photocatalytic denitration. At optimal conditions $\left(73 \mathrm{mg} / \mathrm{m}^{3} \mathrm{NO}, 8 \% \mathrm{O}_{2}, 5 \%\right.$ $\mathrm{H}_{2} \mathrm{O}$ ), NO removal efficiency of $46 \%$ was achieved. In addition, the reaction mechanism of denitration was proposed.
\end{abstract}

(C) 2014, Dalian Institute of Chemical Physics, Chinese Academy of Sciences. Published by Elsevier B.V. All rights reserved.

\section{Introduction}

The major sources of NO are coal power plants and the combustion of fossil fuels in automobiles. Acid rain and photochemical fog caused by NO emission have led to great harm to environment and human health [1,2]. Most coal-fired power plants are equipped with selective catalytic reduction (SCR) systems or selective non-catalytic reduction (SNCR) systems to control NO emission. Although SCR performs effectively in NO reduction, problems such as the expense of operating the catalytic system and catalyst poisoning need to be tackled. Although NO is decomposed without a catalyst in the case of SNCR, practical constraints including the temperature window and time lead to worse NO removal efficiency [3-5]. Photocatalytic technology has received wide-ranging attention as a promising way to remove the various toxic pollutants in flue gas. $\mathrm{TiO}_{2}$ has been widely applied due to its stability, nontoxicity, and high photocatalytic reactivity [6]. Wang et al. [7] used $\mathrm{TiO}_{2}$ loaded on woven glass fabric to remove nitrogen oxides by photocatalytic oxidation. Zhao et al. [8] studied the photocatalytic oxidation of NO with supported nano-TiO2. However, low removal efficiencies are achieved in practice by $\mathrm{TiO}_{2}$ due to its wide energy band gap (3.2 eV) and easy recombination of electron-hole pairs. Many studies have emphasized the modification of $\mathrm{TiO}_{2}$ to increase yields of radicals and shift the adsorption edges toward the visible light region. $\mathrm{N}$-doped $\mathrm{TiO}_{2}$ prepared by Ananpattarachai et al. [9] and $\mathrm{B}$-doped $\mathrm{TiO}_{2}$ synthesized by Li et al. [10] revealed that the introduction of dopants can reduce the band gap of $\mathrm{TiO}_{2}$. Li et al. [11] reported that $\mathrm{Cu}$-tetracarboxyphthalocyanine sensitized mesoporous $\mathrm{TiO}_{2}$

\footnotetext{
*Corresponding author. Tel: +86-25-85481132; Fax: +86-25-85481273; E-mail: yanghongmin@njnu.edu.cn This work was supported by the National Natural Science Foundation of China (50976049), the Natural Science Foundation of Jiangsu (BK2011788) and Research Innovation Program for College Graduates of Jiangsu Province (CXLX12-0410). DOI: 10.1016/S1872-2067(12)60705-0 | http://www.sciencedirect.com/science/journal/18722067 | Chin. J. Catal., Vol. 35, No. 1, January 2014
} 
performed effectively under visible light. Multi-walled carbon nanotubes (MWCNTs) have also been the focus of considerable numbers of studies because of their excellent mechanical, electrical, thermal, and magnetic properties [12]. Wang et al. [13] synthesized MWCNTs-TiO 2 using a sol-gel method and evaluated their photocatalytic ability by phenol decomposition. Yang et al. [14] used $\mathrm{CNT}^{-\mathrm{TiO}_{2}}$ synthesized by a hydrothermal method to decompose methyl orange. In previous investigations, the main concerns of most studies focused on MWCNTs/ $\mathrm{TiO}_{2}$ have been mostly to do with their physicochemical properties and the photocatalytic reaction mechanism. The photocatalytic abilities of these materials were evaluated by the decomposition of dyes, phenol, etc. Seldom has research focused on the photocatalytic removal of NO from flue gas by MWCNTs/ $\mathrm{TiO}_{2}$ been reported.

In this paper, MWCNTs/ $/ \mathrm{TiO}_{2}$ was synthesized by a sol-gel method and characterized by transmission electron microscopy (TEM), X-ray photoelectron spectroscopy (XPS), X-ray diffraction (XRD), and ultraviolet-visible (UV-Vis) diffuse reflectance spectroscopy to give insight into its physicochemical properties. Systematic photocatalytic NO removal experiments were conducted for the first time. Influencing factors $\mathrm{O}_{2}, \mathrm{H}_{2} \mathrm{O}$, $\mathrm{SO}_{2}$, and NO) and the effect of the MWCNTs on the NO removal were studied, and a possible reaction mechanism for the denitration was proposed.

\section{Experimental}

\subsection{Preparation of $M W C N T s / \mathrm{TiO}_{2}$}

Raw MWCNTs were purchased from Chengdu Organic Chemicals Company (purity > 95\%, diameter 10-20 nm, length 10-30 $\mu \mathrm{m}$ ). The raw MWCNTs were acid-treated and functionalized in a mixture of concentrated sulphuric acid and nitric acid (Nanjing Chemical Reagent Company, Nanjing, China) in a volume ratio of 3:1. The acid-treated MWCNTs were rinsed with distilled water until they reached neutral $\mathrm{pH}$ and were then dried at $80^{\circ} \mathrm{C}$ for $12 \mathrm{~h}$.

MWCNTs $/ \mathrm{TiO}_{2}$ was synthesized by a sol-gel method. In a typical synthesis, a certain amount of acid-treated MWCNTs was sonicated in a solution containing $75 \mathrm{~mL}$ anhydrous ethanol (AR, Nanjing Chemical Reagent Company, Nanjing, China), 25 mL tetrabutyl titanate (AR, Nanjing Chemical Reagent Company, Nanjing, China), and $4 \mathrm{~mL} \mathrm{HNO}_{3}$ under vigorous stirring. After stirring for $1 \mathrm{~h}$, a mixture of $25 \mathrm{~mL}$ anhydrous ethanol and $5 \mathrm{~mL}$ distilled water (the $\mathrm{PH}$ was adjusted to about 2) was added dropwise to the solution. The resultant gel was dried at $80{ }^{\circ} \mathrm{C}$ and then calcined at $350-650{ }^{\circ} \mathrm{C}$ in air for $3 \mathrm{~h}$. Bare $\mathrm{TiO}_{2}$ was used as a control sample, following similar preparation steps to those mentioned above. To avoid aggregation of the photocatalysts above the quartz air distributor, all tested photocatalysts were loaded on heat-pretreated silica gel having a diameter of $2 \mathrm{~cm}$. The loading method was detailed in the work of Sannino et al. [15].

\subsection{Characterization of MWCNTs $/ \mathrm{TiO}_{2}$}

The bare $\mathrm{TiO}_{2}$ and composites were characterized using a range of analytical techniques. TEM observations were made with a JEOL JEM-2100F microscope at $200 \mathrm{kV}$. Samples for imaging were sonicated in anhydrous ethanol and collected on a copper carbon-coated TEM grid. The chemical compositions of the MWCNTs $/ \mathrm{TiO}_{2}$ were studied by XPS using a PHI Quantera. XRD was performed to characterize the phase composition and crystal structure of the photocatalysts using a Rigaku D/max-2500/PC X-ray diffractometer with $\mathrm{Cu} K_{\alpha}$ radiation from $5^{\circ}$ to $85^{\circ}$ at a scanning speed of $0.02^{\circ} / \mathrm{s}$. The UV-Vis diffuse reflectance spectra of the composites were measured on a VARIAN Cary 5000 spectrophotometer.

\subsection{Photocatalyst test}

The schematic of the experimental system is shown in Fig. 1. The experiments were conducted in a fixed-bed photoreactor

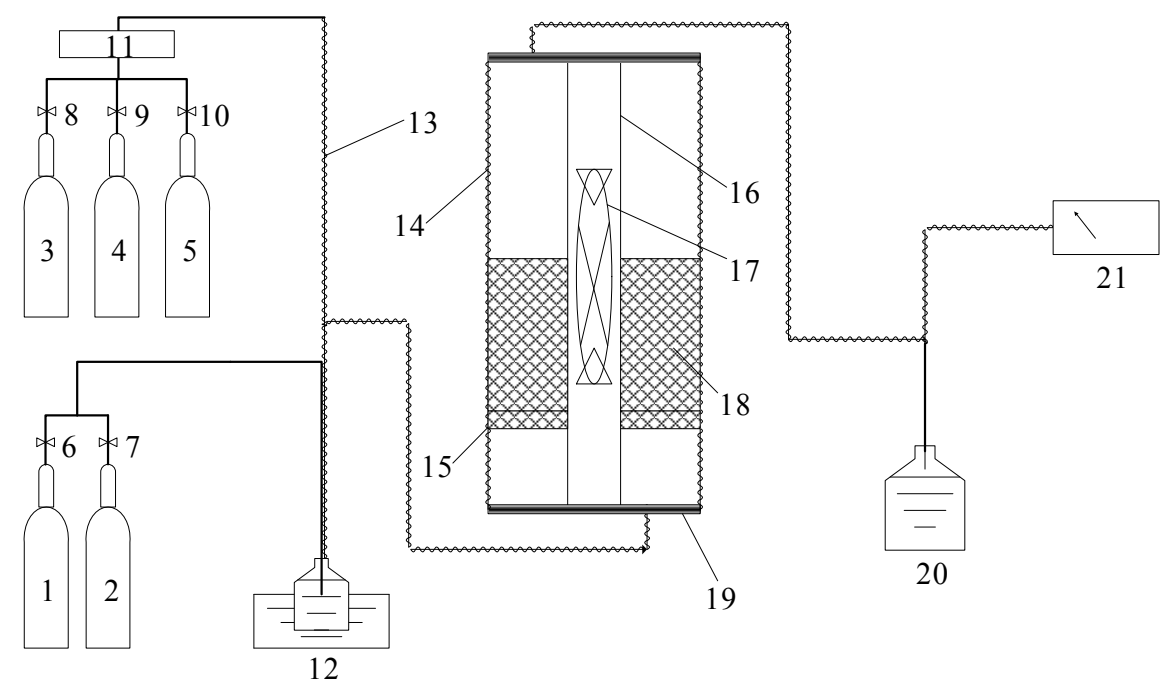

Fig. 1. Schematic diagram of the photoreactor system. 1,3- $\mathrm{N}_{2}$ gas cylinders; $2-\mathrm{O}_{2}$ gas cylinders; 4-NO gas cylinders; $5-\mathrm{SO} \mathrm{O}_{2}$ gas cylinders; 6,7,8,9,10-Mass flow meters; 12-Water bubbler; 13-Heating belts; 14-Outer tube; 15-Quartz air distributor; 16-Inner tube; 17-High pressure mercury lamp; 18-Photocatalysts; 19-Rubber plug; 20-Absorption chamber; 21-Flue gas analyzer. 
comprised of $60 \mathrm{~cm}$-long double concentric quartz tubes. The diameters of the inner and outer tubes were 28 and $60 \mathrm{~mm}$, respectively. A $125 \mathrm{~W}$ high pressure mercury lamp (Shanghai Jiguang Lighting Company, Shanghai, China) was placed vertically in the inner tube as the UV source. The intensity provided by the lamp was $6.5 \mathrm{~W} / \mathrm{m}^{2}$ at the peak wavelength of $365 \mathrm{~nm}$. The composition of the simulated flue gases was $0-8 \% \mathrm{O}_{2}$, 0-15\% $\mathrm{H}_{2} \mathrm{O}, 73-508 \mathrm{mg} / \mathrm{m}^{3} \mathrm{NO}, 155-1241 \mathrm{mg} / \mathrm{m}^{3} \mathrm{SO}_{2}$, and $\mathrm{N}_{2}$ as balance. $\mathrm{O}_{2}, \mathrm{SO}_{2}$, NO, and $\mathrm{N}_{2}$ were supplied from gas cylinders, and the flow rates of the different gases were controlled by a mass flow meter (Beijing Metron Instrument Company, Beijing, China). The $\mathrm{N}_{2}$ flow was divided into two streams. One stream combined with $\mathrm{O}_{2}$ and was allowed to pass through a water bubbler to set the desired water vapor level. The second stream was converged with NO. The total flow rate remained constant at $2 \mathrm{~L} / \mathrm{min}$ and a space velocity of $250 \mathrm{~h}^{-1}$. An ECOM-J2KN (RBR Company, German) was situated downstream to the fixed-bed photoreactor to record the concentration of NO in real time. Adsorption equilibrium of the photocatalysts was achieved by introducing NO into the system before switching on the UV light. The reaction time was set to 15 min for each experiment. NO removal efficiency could be defined as $R_{\mathrm{NO}}=\left[\left(\mathrm{NO}_{\text {in }}-\mathrm{NO}_{\text {out }}\right) / \mathrm{NO}_{\text {in }}\right] \times 100 \%$, where $\mathrm{NO}_{\text {in }}$ and $\mathrm{NO}_{\text {out }}$ represent the NO in the inlet and outlet of the photochemical reactor, respectively.

The experimental conditions are listed in Table 1. To examine the reaction mechanism involved in the photocatalytic removal of NO, Case 1 was conducted to investigate the adsorption of NO on MWCNTs/TiO 2 . In Case 2, photocatalytic denitration was conducted under different conditions (UV, Silica gel, $\mathrm{TiO}_{2}, \mathrm{MWCNTs} / \mathrm{TiO}_{2}$ ). Cases 3-6 were carried out to study the effects of $\mathrm{NO}, \mathrm{O}_{2}, \mathrm{H}_{2} \mathrm{O}$, and $\mathrm{SO}_{2}$ on $\mathrm{NO}$ removal. The amount of photocatalysts used in photocatalytic denitration was $25 \mathrm{~g}$.

\section{Results and discussion}

\subsection{Morphology}

Figure 2 shows TEM images of MWCNTs and MWCNTs/ $\mathrm{TiO}_{2}$. It was found in Fig. 2(a) that the aggregation of the MWCNTs as well as amorphous carbon and impurities on the surface of the MWCNTs. The external diameter of the raw MWCNTs was 15-30 nm. Figure 2(b) shows the typical hollow structures of MWCNTs. After acid-treatment, opening of the tube ends and breakage of the tubes were also observed. For MWCNTs/TiO 2 sample (Fig. 2(c)), MWCNTs were wrapped with $\mathrm{TiO}_{2}$ having an external diameter larger than $20 \mathrm{~nm}$, confirming tight connection between them.

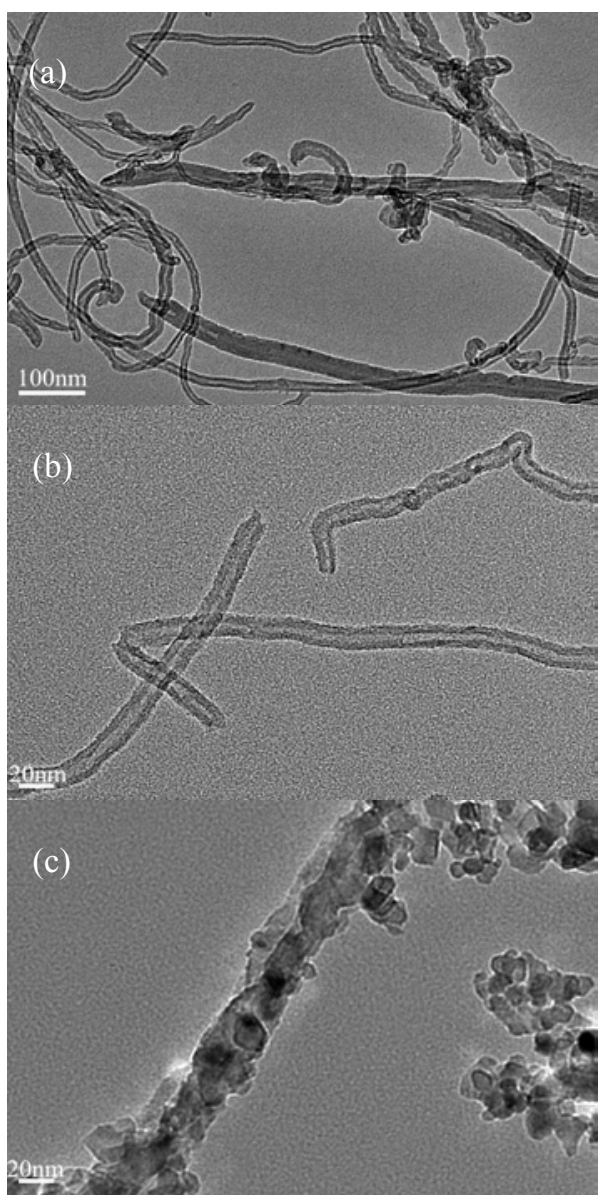

Fig. 2. TEM images of raw MWCNTs (a), acid-treated MWCNTs (b), and MWCNTs $/ \mathrm{TiO}_{2}$ (c) samples.

\subsection{Crystalline phase characterization}

Figure 3 shows the XRD patterns of MWCNTs/TiO 2 calcined at different temperatures. MWCNTs/TiO 2 calcined at 350 and $500{ }^{\circ} \mathrm{C}$ consisted mainly of anatase phase, and the typical diffraction peaks were found at $25.1^{\circ}, 36.9^{\circ}, 37.6^{\circ}, 38.5^{\circ}, 47.9^{\circ}$, $53.8^{\circ}, 55.0^{\circ}, 62.6^{\circ}$, and $75.1^{\circ}$, corresponding to the reflections from (101), (103), (004), (112), (200), (105), (211), (204), and (215) crystal planes, respectively, of the anatase phase. The full width at half maximum of (101) for MWCNTs/TiO 2 calcined at $500{ }^{\circ} \mathrm{C}$ was shorter than that calcined at $350{ }^{\circ} \mathrm{C}$, indicating an increase in crystallinity. Significant phase transformation was induced by heat-treatment at $650{ }^{\circ} \mathrm{C}$. The anatase phase transformed mostly to the rutile phase, indicated by the typical rutile diffraction peak observed at $27.4^{\circ}$. Moreover, the weight of samples calcined at $650{ }^{\circ} \mathrm{C}$ as measured by analytical balance

\section{Table 1}

Experimental conditions for photocatalytic removal of NO.

\begin{tabular}{|c|c|c|c|c|c|c|}
\hline Case & $\mathrm{O}_{2}(\%)$ & $\mathrm{H}_{2} \mathrm{O}(\%)$ & $\mathrm{NO}\left(\mathrm{mg} / \mathrm{m}^{3}\right)$ & $\mathrm{SO}_{2}\left(\mathrm{mg} / \mathrm{m}^{3}\right)$ & Material & UV light \\
\hline 1 & 8 & 5 & 181 & - & MWCNTs/TiO 2 & off \\
\hline 2 & 8 & 5 & 73 & - & Silica gel, $\mathrm{TiO}_{2}, \mathrm{MWCNTs} / \mathrm{TiO}_{2}$ & on \\
\hline 3 & 8 & 5 & 73/181/254/508 & - & MWCNTs/ $/ \mathrm{TiO}_{2}$ & on \\
\hline 4 & $0 / 3 / 6 / 8$ & 5 & 73 & - & MWCNTs $/ \mathrm{TiO}_{2}$ & on \\
\hline 5 & 8 & $0 / 1 / 5 / 15$ & 73 & - & MWCNTs/ $/ \mathrm{TiO}_{2}$ & on \\
\hline 6 & 8 & 5 & 73 & $155 / 310 / 620 / 1241$ & MWCNTs/ $/ \mathrm{TiO}_{2}$ & on \\
\hline
\end{tabular}




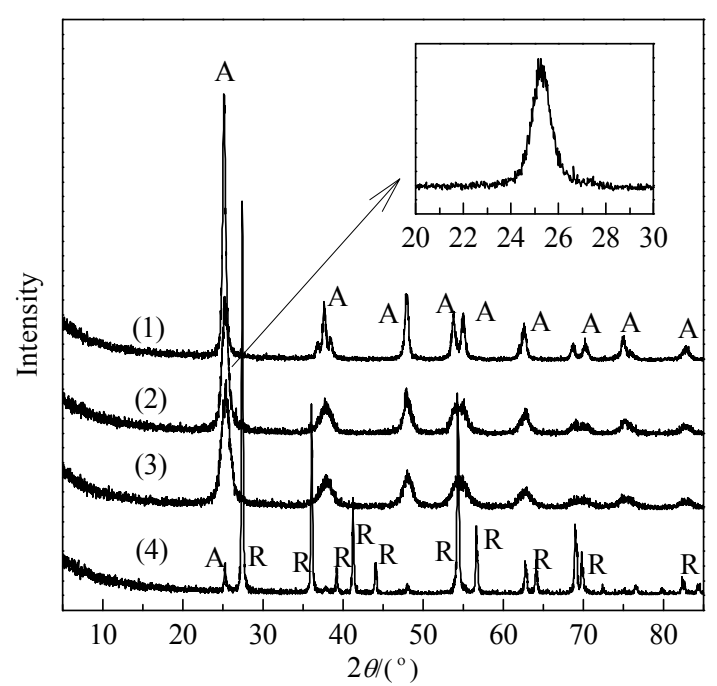

Fig. 3. XRD patterns of MWCNTs $/ \mathrm{TiO}_{2}$ calcined at different temperatures. (1) $\mathrm{TiO}_{2}, 500{ }^{\circ} \mathrm{C}$; (2) MWCNTs/ $\mathrm{TiO}_{2}, 350{ }^{\circ} \mathrm{C}$; (3) $\mathrm{MWCNTs} / \mathrm{TiO}_{2}$, $500{ }^{\circ} \mathrm{C}$; (4) MWCNTs $/ \mathrm{TiO}_{2}, 650^{\circ} \mathrm{C}$.

(AUX320, SHIMADZU, Japan) decreased significantly compared with that of samples heat-treated at $500{ }^{\circ} \mathrm{C}$ (the weight of sample heat-treated at $500{ }^{\circ} \mathrm{C}$ was approximate to the theoretical value during preparation), revealing that heat-treatment at 650 ${ }^{\circ} \mathrm{C}$ led to MWCNTs oxidation loss. Li et al. [16] also confirmed a significant weight loss for MWCNTs at $550-750{ }^{\circ} \mathrm{C}$ in TGA experiments. Contaminant phases were not observed during XRD analysis. Cong et al. [17] reported that the (002) reflection of MWCNTs was overlapped by (101) of $\mathrm{TiO}_{2}$ due to their proximity at $26.3^{\circ}$ and $25.3^{\circ}$, respectively. No diffraction peak from the
MWCNTs was found after peak fitting at $20^{\circ}-30^{\circ}$, and the absent (002) reflection was attributed to the low content and uniform dispersion of the MWCNTs. The (101) peak of MWCNTs $/ \mathrm{TiO}_{2}$ calcined at $500{ }^{\circ} \mathrm{C}$ was broadened compared with that of bare $\mathrm{TiO}_{2}$, which correlated closely with the decreased crystallite size. Scherrer's formula was used to give an approximate calculation of crystallite size based on the FWHM of the (101) peak. The crystallite sizes of $\mathrm{TiO}_{2}$ and MWCNTs/ $\mathrm{TiO}_{2}$ calcined at $500{ }^{\circ} \mathrm{C}$ were thereby found to be 19.1 and 11 $\mathrm{nm}$, respectively, suggesting that the MWCNTs inhibited the grain growth of $\mathrm{TiO}_{2}$ during crystallization. The average $\mathrm{TiO}_{2}$ particle size estimated from the TEM images was about $15 \mathrm{~nm}$, larger than that calculated from XRD. According to Lin et al. [18], a larger TEM estimated size is attributable to the aggregation of $\mathrm{TiO}_{2}$ nanoparticles into larger particles, while XRD calculates the size of single crystallites. MWCNTs/TiO 2 calcined at $500{ }^{\circ} \mathrm{C}$ was used for photocatalyst test.

\subsection{XPS analysis}

Figure 4(a) shows XPS spectrum of MWCNTs/TiO 2 and clearly reveals that the main elements on the sample surface were $\mathrm{Ti}, \mathrm{C}$, and $\mathrm{O}$. Figure $4(\mathrm{~b})$ displays the $\mathrm{C} 1 \mathrm{~s}$ spectra of the MWCNTs/ $/ \mathrm{TiO}_{2}$ sample. Three peaks were observed in the $\mathrm{C} 1 \mathrm{~s}$ spectra after peak fitting. The main peak was located at 284.6 $\mathrm{eV}$, ascribed to graphitic carbon and $\mathrm{C}-\mathrm{C}$ bonds from MWCNTs. The second at $285.9 \mathrm{eV}$ was attributed to $\mathrm{C}-\mathrm{O}$ bonds, and the broad peak located at $287.9 \mathrm{eV}$ represented $\mathrm{C}=\mathrm{O}$ and $\mathrm{COO}$ bonds [17]. Figure 4(c) shows the 01s spectra of the sample, which was fitted into three peaks. The $01 s$ peak at $530.1 \mathrm{eV}$ corresponded to lattice oxygen, while the higher binding ener-
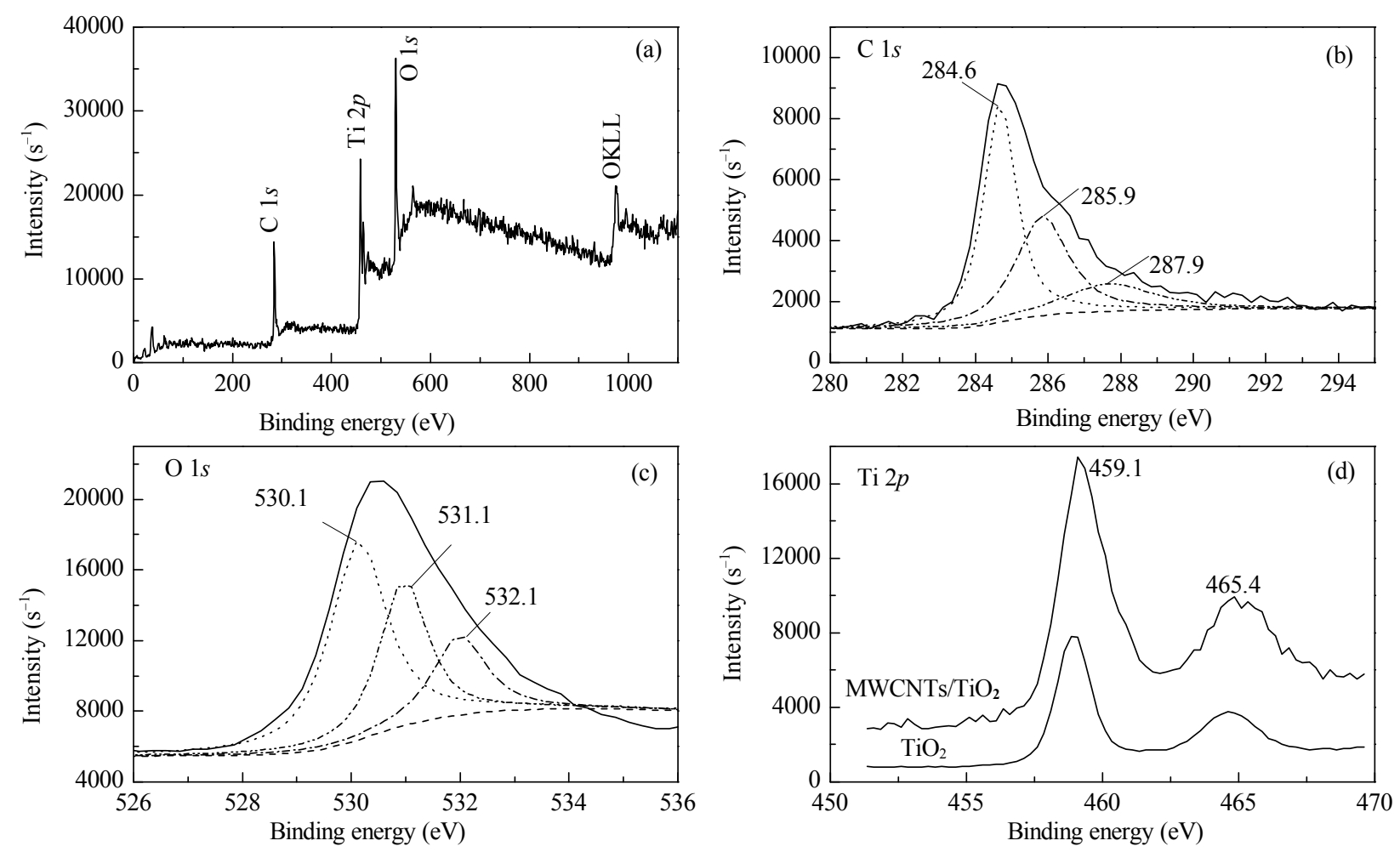

Fig. 4. XPS spectra of MWCNTs/ $\mathrm{TiO}_{2}$ sample. (a) General XPS spectrum; (b-d) XPS spectra of C $1 s, 01 s$, and Ti $2 p$. 
gies of 531.1 and $532.1 \mathrm{eV}$ were assigned to surface hydroxyl oxygen and $\mathrm{C}-\mathrm{O}$ bonds, respectively $[17,19]$. Obviously, Ti-O and $\mathrm{C}-\mathrm{O}$ bonds present in the $\mathrm{C} 1 s$ and $01 s$ XPS spectra after peak fitting led to the anticipation of intimate connection between MWCNTs and $\mathrm{TiO}_{2}$ through Ti-O-C bonds. Figure 4(d) reveals the $\mathrm{Ti}\left(2 p_{3 / 2}, 2 p_{1 / 2}\right)$ spectra. The binding energies of $\mathrm{Ti}$ $2 p_{3 / 2}$ and Ti $2 p_{1 / 2}$ were 459.1 and $465.4 \mathrm{eV}$, respectively, indicating the typical presence of $\mathrm{Ti}^{4+}$ in the $\mathrm{TiO}_{2}$. Moreover, increases in the binding energies of Ti $2 p$ compared with that of bare $\mathrm{TiO}_{2}$ were observed and assigned to electrons transferring through $\mathrm{Ti}-\mathrm{O}-\mathrm{C}$ bonds changing the electron density of $\mathrm{Ti}^{4+}$ in $\mathrm{TiO}_{2}$.

\subsection{Optical properties}

The UV-Vis DRS spectra of MWCNTs/ $/ \mathrm{TiO}_{2}$ and $\mathrm{TiO}_{2}$ are presented in Fig. 5(a). $\mathrm{TiO}_{2}$ showed a typical adsorption edge at about $400 \mathrm{~nm}$ and weak absorption in the visible light region. In contrast, a positive effect could be observed in the presence of MWCNTs; the absorption edge was red-shifted toward the long wavelength region. This shift suggested a decrease in the Fermi level induced by electron transfer through Ti-O-C bonds [20]. Moreover, the MWCNTs $/ \mathrm{TiO}_{2}$ composite exhibited enhanced visible-light-absorption efficiency compared with that of bare $\mathrm{TiO}_{2}$, which was attributed to the possible electronic transition $\pi \rightarrow \pi^{*}$ in the MWCNTs and the black color of the photocatalysts [21]. Figure 5(b) shows a plot of $[F(R) h v]^{1 / 2}$ versus photo energy. The extrapolation of $[F(R) h v]^{1 / 2}$ to the abscissa at zero $F(R)$ provided the band gap energies of MWCNTs/ $/ \mathrm{TiO}_{2}$ and $\mathrm{TiO}_{2}$ to be 2.6 and $3.0 \mathrm{eV}$, respectively, confirming the narrowed band gap energy of MWCNTs/TiO 2 .

\subsection{Photocatalytic denitration}

\subsubsection{Baseline experiments}

Figure 6 reveals the NO adsorption ability of MWCNTs/ $\mathrm{TiO}_{2}$. To measure the NO adsorption of the photocatalyst, NO was first introduced into the bypass and maintained steadily at 189 $\mathrm{mg} / \mathrm{m}^{3}$. The bypass valve was then shut, and NO was introduced into the reactor, which contained the photocatalyst. The NO concentration decreased sharply at first and reached a minimum of $162 \mathrm{mg} / \mathrm{m}^{3}$ after $3 \mathrm{~min}$. The NO concentration

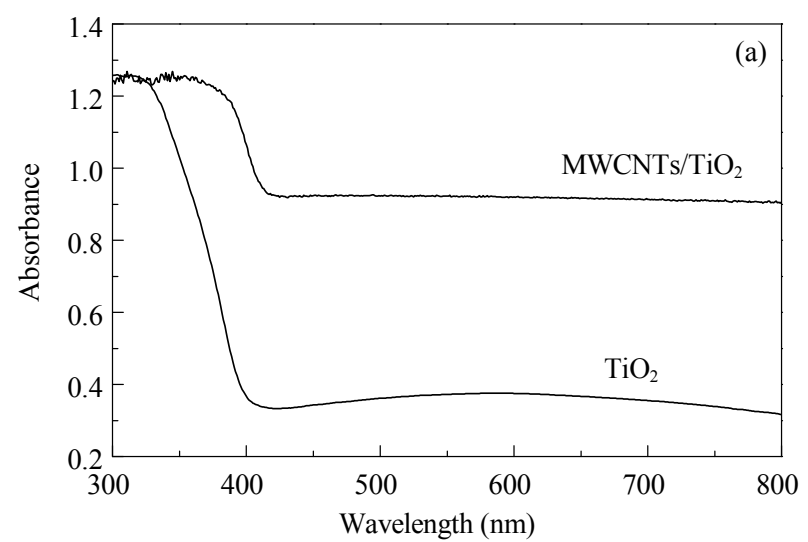

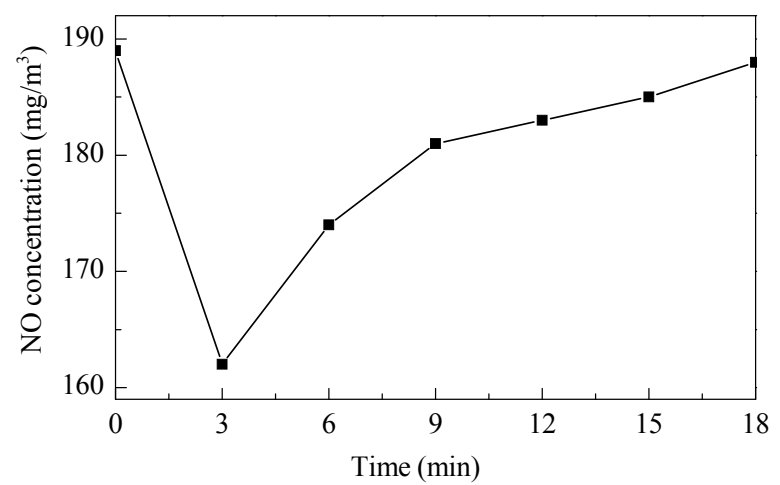

Fig. 6. NO adsorption performance of $\mathrm{MWCNTs} / \mathrm{TiO}_{2}$ loaded on silica gel.

then started to increase and reached its original level after 18 min. The maximum NO adsorption efficiency was $14 \%$.

Figure 7 shows the results of photocatalytic denitration conducted under different conditions (UV, silica gel, $\mathrm{TiO}_{2}$, MWCNTs/ $/ \mathrm{TiO}_{2}$ ). Some NO reaction occurred under UV irradiation even in the absence of photocatalyst, and $R_{\text {No }}$ was about $16 \%$. The reaction mechanism for NO removal was similar to that for formation of photochemical smog. Active 0 formed by $\mathrm{NO}_{2}$ photolysis and $\mathrm{O}_{3}$ formed by $\mathrm{O}$ reacting with $\mathrm{O}_{2}$ were able to oxidize NO to higher valence state. The reaction mechanism [22] induced by UV irradiation can be defined by reactions (1)-(6):

$$
\begin{aligned}
\mathrm{NO}_{2}+h v & \rightarrow \mathrm{NO}+\mathrm{O} \\
\mathrm{O}+\mathrm{O}_{2} & \rightarrow \mathrm{O}_{3}+\mathrm{O}+\mathrm{M} \\
\mathrm{O}_{3}+\mathrm{NO} & \rightarrow \mathrm{NO}_{2}+\mathrm{O}_{2} \\
\mathrm{O}+\mathrm{NO}+\mathrm{M} & \rightarrow \mathrm{NO}_{2}+\mathrm{M} \\
\mathrm{O}+\mathrm{NO}_{2}+\mathrm{M} & \rightarrow \mathrm{NO}_{3}+\mathrm{M} \\
\mathrm{O}_{3}+\mathrm{NO}_{2}+\mathrm{M} & \rightarrow \mathrm{NO}_{3}+\mathrm{O}_{2}+\mathrm{M}
\end{aligned}
$$

To increase the interfacial area for vapor-solid contact and reaction time, MWCNTs $/ \mathrm{TiO}_{2}$ was loaded onto silica gel for the photocatalytic experiments. It was therefore necessary to investigate the role of silica gel in photocatalytic denitration. Figure 7 indicates that no remarkable NO reaction was observed on the silica gel. However, $R_{\text {No }}$ decreased slightly compared with the case without photocatalyst. This decrease in $R_{\mathrm{N} O}$ was expected to result from photon energy loss caused by refraction and reflection of UV light by the silica gel. In denitration

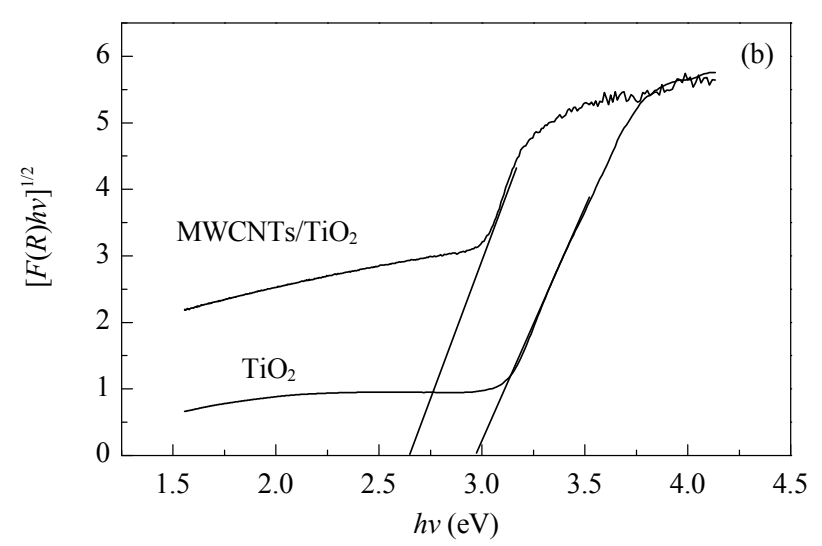

Fig. 5. (a) DRS spectra of $\mathrm{MWCNTs} / \mathrm{TiO}_{2}$ and $\mathrm{TiO}_{2}$; (b) Plot of $[F(R) h v]^{1 / 2}$ vs photon energy of $\mathrm{TiO}_{2}$ and $\mathrm{MWCNTs} / \mathrm{TiO}_{2}$. 


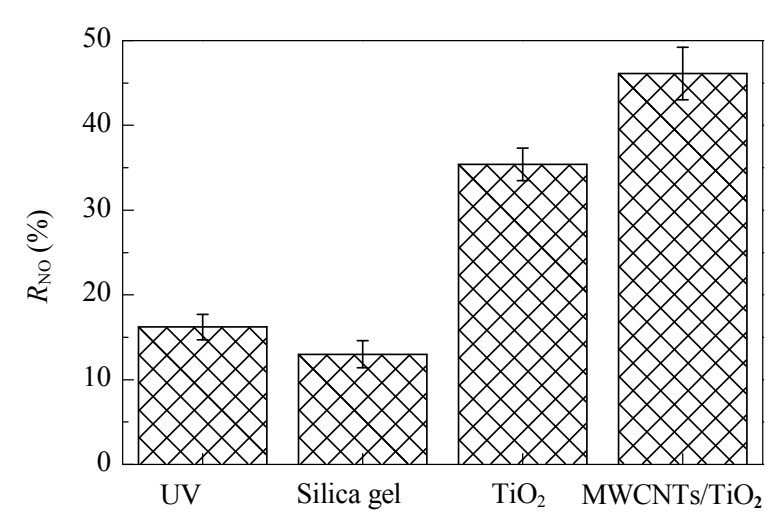

Fig. 7. Effect of UV and various types of photocatalysts on NO removal.

experiments, the effect of the silica gel on $R_{\mathrm{N}}$ was negligible.

Compared with the case without photocatalyst, MWCNTs/ $\mathrm{TiO}_{2}$ and $\mathrm{TiO}_{2}$ performed well in photocatalytic denitration, the $R_{\text {NO }}$ of which reached $46 \%$ and $35 \%$ respectively. The results revealed that the process of photocatalytic NO removal was more effective than the photochemical NO removal process. In the presence of photocatalyst, the incident UV radiation ejected electrons from the valence band of the photocatalyst to the conduction band. The photogenerated electrons and holes formed diffused toward the photocatalyst surface. Once the photoinduced electrons and holes have been trapped by surface adsorbed species like $\mathrm{O}_{2}$ and $\mathrm{H}_{2} \mathrm{O}$, active $\mathrm{O}_{2}{ }^{-}$and $\cdot \mathrm{OH}$ were formed and were capable of oxidizing $\mathrm{NO}$ to $\mathrm{NO}_{2}, \mathrm{HNO}_{2}$, or $\mathrm{HNO}_{3}$. It was reported by Devahasdin et al. [23] that NO oxidation involves the following series of steps: $\mathrm{NO} \rightarrow \mathrm{HNO}_{2} \rightarrow \mathrm{NO}_{2} \rightarrow$ $\mathrm{HNO}_{3}$. In the initial stage, $\mathrm{HNO}_{2}$ was the dominating reaction product. Once the photocatalysts were saturated with $\mathrm{HNO}_{3}$, $\mathrm{NO}_{2}$ to $\mathrm{HNO}_{3}$ conversion was inhibited, and the reaction only went as far as $\mathrm{NO}_{2}$. The reaction mechanism [23,24] for NO removal in the presence of photocatalyst can be defined by reactions (7)-(13):

$$
\begin{aligned}
\mathrm{TiO}_{2}+h v & \rightarrow \mathrm{e}^{-}+\mathrm{h}^{+} \\
\mathrm{h}^{+}+\mathrm{OH}^{-} & \rightarrow \cdot \mathrm{OH} \\
\mathrm{e}^{-}+\mathrm{O}_{2} & \rightarrow \mathrm{O}_{2}^{-} \\
\mathrm{NO}+\cdot \mathrm{OH} & \rightarrow \mathrm{HNO}_{2} \\
\mathrm{HNO}_{2}+\cdot \mathrm{OH} & \rightarrow \mathrm{NO}_{2} \\
\mathrm{NO}_{2}+\cdot \mathrm{OH} & \rightarrow \mathrm{NO}_{3}^{-} \\
\mathrm{NO}+\mathrm{O}_{2}^{-} & \rightarrow \mathrm{NO}_{3}^{-}
\end{aligned}
$$

\subsubsection{The effect of MWCNT}

As shown in Fig. 7, a positive effect of MWCNTs on NO removal was observed; $46 \%$ of $R_{\mathrm{NO}}$ was achieved on MWCNTs $/ \mathrm{TiO}_{2}$ compared with $35 \%$ of $R_{\mathrm{NO}}$ on bare $\mathrm{TiO}_{2}$. This enhancement could be attributed to the following three aspects. The first is good conductivity of MWCNTs. Considering the limited pathways for electron transfer in bare $\mathrm{TiO}_{2}$, the MWCNTs provided alternative pathways for electrons to transfer through $\mathrm{Ti}-\mathrm{O}-\mathrm{C}$ bonds, prolonging electron-hole pair lifetimes $[25,26]$. The second is the smaller crystallite size of MWCNTs/TiO 2 . XRD analysis confirmed that introducing MWCNTs inhibited the grain growth of the $\mathrm{TiO}_{2}$. Devi et al. [27] suggested that volume recombination dominated the possible ways for electron-hole recombination. Large crystallite sizes, which result in longer diffusion path length, allowed more chance for electron-hole recombination. Hence, smaller crystallite size favors the diffusion of more electrons and holes to the surface. The third is the narrow band gap energy of MWCNTs/ $\mathrm{TiO}_{2}$. In DRS analysis, the adsorption edge of MWCNTs/TiO was found to be shifted toward longer wavelengths compared with that of bare $\mathrm{TiO}_{2}$. It was expected that more electron-hole pairs were created at the same UV intensity as a result of this red shift.

\subsubsection{The effect of gas components}

Figure 8(a) underlines the effect of NO initial concentration on NO removal. $R_{\text {No }}$ decreased sharply at first and then leveled off with increasing NO. These results indicated that a lower initial NO concentration was conducive to NO removal. The behavior depicted in Fig. 8(a) revealed that the NO removal reaction was ruled by the Langmiur-Hinshelwood model, namely first-order reaction at low concentration and zero-order reaction at high concentration [7]. Because a great deal of $\mathrm{SO}_{2}$ is emitted from power plants during the combustion of coal, it was necessary to investigate the effect of $\mathrm{SO}_{2}$ on $\mathrm{NO}$ removal. As shown in Fig. 8(b), RNo declined sharply to $39 \%$ when $155 \mathrm{mg} / \mathrm{m}^{3} \mathrm{SO}_{2}$ was introduced into the system and further declined to $29 \%$ at $1241 \mathrm{mg} / \mathrm{m}^{3} \mathrm{SO}_{2}$, a remarkable decrease compared with the initial value of $R_{\mathrm{N}}$ in the absence of $\mathrm{SO}_{2}$. The decrease in $R_{\mathrm{NO}}$ under complex gas atmosphere was attributed to $\mathrm{SO}_{2}$ and $\mathrm{NO}$ competing for the limited adsorption and reaction sites. Li et al. [28] reported that surface hydroxyl groups are the dominant adsorption sites for NO, while surface

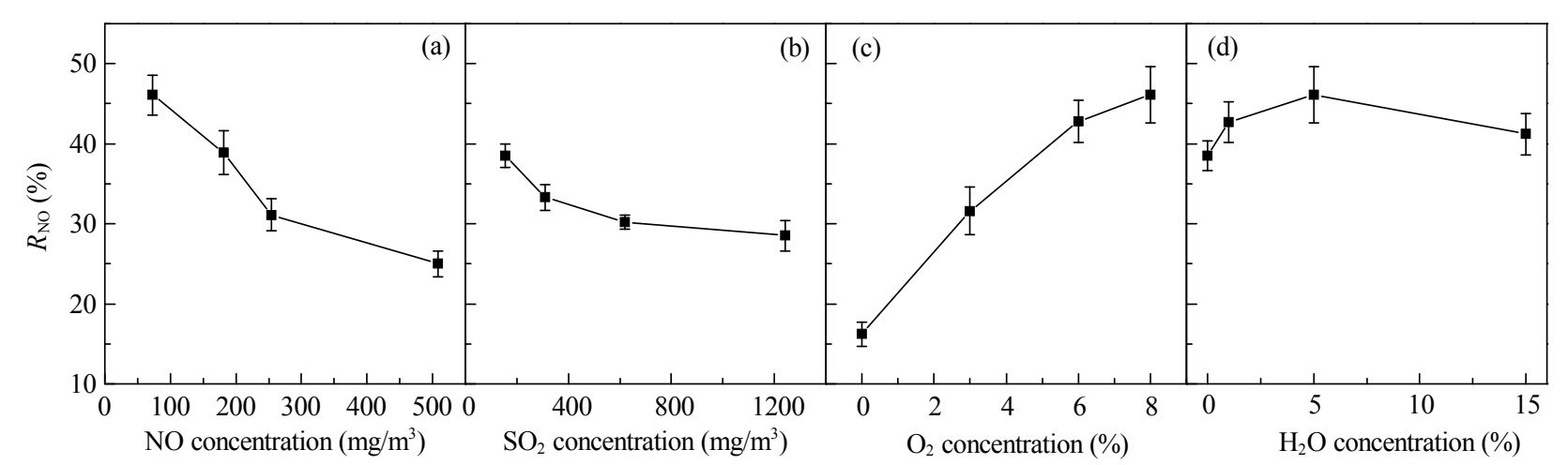

Fig. 8. Effect of initial $\mathrm{NO}(\mathrm{a}), \mathrm{SO}_{2}(\mathrm{~b}), \mathrm{O}_{2}(\mathrm{c})$, and $\mathrm{H}_{2} \mathrm{O}$ (d) concentrations on NO removal Efficiency $\left(R_{\mathrm{NO}}\right)$. 
hydroxyl groups and lattice oxygen are responsible for adsorption of $\mathrm{SO}_{2}$ [29]. A lower $\mathrm{R}_{\mathrm{NO}}$ was therefore as a result of $\mathrm{SO}_{2}$ and NO competing for the limited surface hydroxyl groups.

Many studies have suggested positive effects of $\mathrm{O}_{2}$ and $\mathrm{H}_{2} \mathrm{O}$ on photocatalytic oxidation. Figure 8(c) reveals the effect of $\mathrm{O}_{2}$ on NO removal. RNO was as low as $17 \%$ in the absence of $\mathrm{O}_{2}$ but increased to $46 \%$ at an $\mathrm{O}_{2}$ content of $8 \%$. Figure $8(\mathrm{~d})$ shows the effect of $\mathrm{H}_{2} \mathrm{O}$ on $\mathrm{NO}$ removal. $R_{\mathrm{NO}}$ increased to a maximum value of $46 \%$ at $5 \% \mathrm{H}_{2} \mathrm{O}$ and then decreased to $41 \%$ at $15 \% \mathrm{H}_{2} \mathrm{O}$. These results indicated that suitable concentrations of $\mathrm{O}_{2}$ and $\mathrm{H}_{2} \mathrm{O}$ played a prominent role in NO removal. Photoinduced electrons and holes were scavenged by $\mathrm{O}_{2}$ and surface hydroxyl groups to form $\mathrm{O}_{2}{ }^{-}$and $\cdot \mathrm{OH}$ (reactions (8) and (9)), which improved reactions (10)-(13) [30]. Hence, the observed enhancement of $R_{\text {No }}$ was justified. However, more studies have focused on studying the effect of $\mathrm{H}_{2} \mathrm{O}$ than that of $\mathrm{O}_{2}$ due to the high activity of $\cdot \mathrm{OH}$ and the both inhibiting and promoting role that $\mathrm{H}_{2} \mathrm{O}$ plays in photocatalytic oxidation. $\mathrm{H}_{2} \mathrm{O}$ plays an important role in the formation of surface hydroxyl groups, which not only acted as adsorption sites for $\mathrm{O}_{2}$ and NO, but also for $\mathrm{H}_{2} \mathrm{O}$ through hydrogen bonding. $R_{\text {No }}$ was enhanced due to the greater amount of hydroxyl groups formed [31]. Zhao et al. [8] observed a negative effect of $\mathrm{H}_{2} \mathrm{O}$ on $\mathrm{NO}$ removal at $\mathrm{H}_{2} \mathrm{O}$ content greater than $6 \%$, but they did not give a cause for the decrease in $R_{\text {No. }}$. However, Henderson [32] revealed that water layers formed outside the photocatalyst were capable of blocking the diffusion of target molecules toward adsorption and reaction sites, and that $\mathrm{O}_{2}$ was also blocked by water layers, inhibiting the formation of $\mathrm{O}_{2}^{-}$. In this paper, a positive role of $\mathrm{H}_{2} \mathrm{O}$ was found in an $\mathrm{H}_{2} \mathrm{O}$ concentration range of $0-5 \%$, while an inhibitory effect was observed at $15 \%$, revealing that a water layer may have formed outside the photocatalyst and blocked the diffusion of the target molecule. In addition, $\mathrm{H}_{2} \mathrm{O}$ has an effect on the migration of the reaction products of photocatalytic denitration, which prevents photocatalyst deactivation [33,34]. Typically, $\mathrm{HNO}_{2}$ and $\mathrm{HNO}_{3}$ are deposited on the $\mathrm{TiO}_{2}$ surface during the NO removal reaction and block the absorption sites of $\mathrm{TiO}_{2}$ for further $\mathrm{NO}$ conversion, and thus deactivation occurs. In the presence of $\mathrm{H}_{2} \mathrm{O}$, adsorbed photocatalytic products, including adsorbed $\mathrm{HNO}_{2}$ and $\mathrm{HNO}_{3}$, are converted into water soluble products, and $\mathrm{H}_{2} \mathrm{O}$ thereby assists in the self-cleaning of photocatalysts.

\section{Conclusions}

MWCNTs $/ \mathrm{TiO}_{2}$ was successfully synthesized using a sol-gel method. The introduction of MWCNTs refined the physical and chemical structure. The decreased crystallite size of MWCNTs/ $\mathrm{TiO}_{2}$ lowered the chance for volume recombination. Moreover, MWCNTs provided alternative electrons transfer pathway to assist in hole-electron pairs separation. These aspects contributed to better denitration performance on MWCNTs/TiO compared to bare $\mathrm{TiO}_{2}$. In the study of photocatalytic denitration, at optimal conditions $\left(73 \mathrm{mg} / \mathrm{m}^{3} \mathrm{NO}, 8 \% \mathrm{O}_{2}, 5 \% \mathrm{H}_{2} \mathrm{O}\right)$, an optimal denitration efficiency of $46 \%$ was observed on MWCNTs/ $/ \mathrm{TiO}_{2}$. A lower NO initial concentration was found to be conducive to NO removal. However, RNo was lower in the presence of $\mathrm{SO}_{2}$, because $\mathrm{SO}_{2}$ and NO competed for limited adsorption and reaction sites. $\mathrm{O}_{2}$ and $\mathrm{H}_{2} \mathrm{O}$ were found to play promotional roles in $\mathrm{NO}$ removal due to the formation of active $\mathrm{O}_{2}{ }^{-}$and $\cdot \mathrm{OH}$ species. For excess $\mathrm{H}_{2} \mathrm{O}$, a water layer may formed outside the photocatalyst to inhibit photocatalytic denitration, and the negative effect of excess $\mathrm{H}_{2} \mathrm{O}(15 \%)$ on $\mathrm{NO}$ removal was observed.

\section{References}

[1] Liang Z Y, Ma X Q, Lin H, Tang Y T. Appl Energy, 2011, 88: 1120

[2] Sun W Y, Ding S L, Zeng S S, Su S J, Jiang W J. J Hazard Mater, 2011, 192: 124

[3] Nguyen T D B, Lim Y I, Eom W H, Kim S J, Yoo K S. Comput Chem Eng, 2010, 34: 1580

[4] Bae S W, Roh S A, Kim S D. Chemosphere, 2006, 65: 170

[5] Roy S, Hegde M S, Madras G. Appl Energy, 2009, 86: 2283

[6] Maggos Th, Bartzis J G, Liakou M, Gobin C. J Hazard Mater, 2007, 146: 668

[7] Wang H Q, Wu Z B, Zhao W R, Guan B H. Chemosphere, 2007, 66: 185

[8] Zhao L, Zhao Y, Han J, Song L Q. Acta Chim Sin (赵莉, 赵毅, 韩静, 宋立琴. 化学学报), 2008, 66: 2001

[9] Ananpattarachai J, Kajitvichyanukul P, Seraphin S. J Hazard Mater, 2009, 168: 253

[10] Li L, Yang Y L, Liu X R, Fan R Q, Shi Y, Li S, Zhang L Y, Fan X, Tang P X, Xu R, Zhang W Z, Wang Y Z, Ma L Q. Appl Surf Sci, 2013, 265: 36

[11] Li X P, Chen F, Zhang J L. Chin J Catal (李晓佩, 陈锋, 张金龙. 催化 学报), 2007, 28: 229

[12] Paradise M, Goswami T. Mater Des, 2007, 28: 1477

[13] Wang W D, Serp P, Kalck P, Silva C G, Faria J L. Mater Res Bull, 2008, 43: 958

[14] Yang H P, Shi Z M, Dai K J, Wu J M. Acta Chim Sin (杨汉培, 石泽敏, 戴开静, 段云平, 吴俊明. 化学学报), 2011, 69: 536

[15] Sannino D, Vaiano V, Ciambelli P, Eloy P, Gaigneaux E M. Appl Catal A, 2011, 394: 71

[16] Li Z Y, Gao B, Chen G Z, Mokaya R, Sotiropoulos S, Puma G L. Appl Catal B, 2011, 110: 50

[17] Cong Y, Li X K, Qin Y, Dong Z J, Yuan G M, Cui Z W, Lai X J. Appl Catal B, 2011, 107: 128

[18] Lin X X, Rong F, Fu D G, Yuan C W. Powder Technol, 2012, 219: 173

[19] Xin B F, Wang P, Ding D D, Liu J, Ren Z Y, Fu H G. Appl Surf Sci, 2008, 254: 2569

[20] Cong Y, Qin Y, Li X K, Dong Z J, Yuan G M, Cui Z W. Acta Phys-Chim $\operatorname{Sin}$ (丛野, 秦云, 李轩科, 董志军, 袁观明, 崔正威. 物理化学学 报), 2011, 27: 1509

[21] Ou Y, Lin J D, Fang S M, Liao D W. Chem Phys Lett, 2006, 429: 199

[22] Smith J P, Urone P. Environ Sci Technol, 1974, 8: 742

[23] Devahasdin S, Fan C Jr, Li K, Chen D H. J Photochem Photobiol A, 2003, 156: 161

[24] Yuan Y, Zhang J Y, Li H L, Li Y, Zhao Y C, Zheng C G. Chem Eng J, 2012, 192: 21

[25] Kuo C Y.J Hazard Mater, 2009, 163: 239

[26] Kongkanand A, Domínguez R M, Kamat P V. Nano Lett, 2007, 7: 676

[27] Devi L G, Murthy B N, Kumar S G. Mater Sci Eng B, 2010, 166: 1

[28] Li S C, Jacobson P, Zhao S L, Gong X Q, Diebold U.J Phys Chem C, 2012, 116: 1887

[29] Baltrusaitis J, Jayaweera P M, Grassian V H. J Phys Chem C, 2010, 115: 492

[30] Lu S Y, Wang Q L, Buekens A G, Yan J H, Li X D, Cen K F. Chem Eng J, 


\title{
Graphical Abstract
}

Chin. J. Catal., 2014, 35: 66-77 doi: 10.1016/S1872-2067(12)60705-0

Photocatalytic removal of nitric oxide by multi-walled carbon nanotubes-supported $\mathrm{TiO}_{2}$

Hao Liu, Hairu Zhang, Hongmin Yang*

Nanjing Normal University;

Design Institute of Nanjing Shengnuo Heat Pipe Co., Ltd

MWCNTs provide another transfer pathway for photogenerated electrons, assisting in electron and hole separation. This electron-scavenging character of MWCNTs causes $\mathrm{MWCNTs} / \mathrm{TiO}_{2}$ to perform better in photocatalytic denitration than bare $\mathrm{TiO}_{2}$.

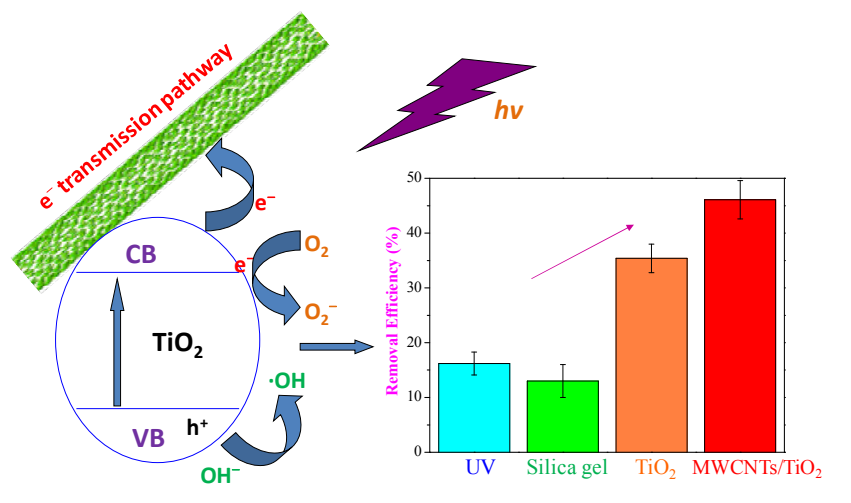

2012, 195-196: 233

[31] Wendt S, Matthiesen J, Schaub R, Vestergaard E K, Lagsgaard E, Besenbacher F, Hammar B. Phys Rev Lett, 2006, 96: 066107
[32] Henderson M A. Surf Sci Rep, 2011, 66: 185

[33] Miller T M, Grassian V H. Geophys Res Lett, 1998, 25: 3835

[34] Guan K S. Surf Coat Technol, 2005, 191: 155

\section{多壁碳纳米管负载 $\mathrm{TiO}_{2}$ 的光催化脱硝性能}

\author{
刘 浩 ${ }^{\mathrm{a}}$, 张海茹 ${ }^{\mathrm{b}}$, 杨宏旻 ${ }^{\mathrm{a},}{ }^{*}$ \\ a南京师范大学能源与机械工程学院, 江苏南京 210042 \\ b南京圣诺热管有限公司设计院, 江苏南京210009
}

摘要: 采用溶胶凝胶法制备了多壁碳纳米管负载 $\mathrm{TiO}_{2}\left(\mathrm{MWCNTs} / \mathrm{TiO}_{2}\right)$, 并利用透射电镜、X射线光电子能谱、X射线衍射和紫外可见漫反射光谱对样品进行了表征. 结果表明, $\mathrm{MWCNTs} / \mathrm{TiO}_{2}$ 晶型以锐钛矿为主, $\mathrm{MWCNTs}$ 的引入会限制 $\mathrm{TiO}_{2}$ 晶粒的生长. 另 外, $\mathrm{MWCNTs} / \mathrm{TiO}_{2}$ 的光吸收边向长波区域偏移. 针对模拟烟气, 在固定床光催化反应器中对采用涂覆处理的 $\mathrm{MWCNTs} / \mathrm{TiO}_{2}$ 的光 催化脱硝性能进行了实验研究. 结果表明, $\mathrm{NO}$ 初始浓度较低时, 光催化脱硝效率较高, $\mathrm{SO}_{2}$ 的存在可抑制光催化脱硝过程, 而 $\mathrm{O}_{2}$ 及 $\mathrm{H}_{2} \mathrm{O}$ 则有促进作用. 在最佳实验条件 $\left(73 \mathrm{mg} / \mathrm{m}^{3} \mathrm{NO}, 8 \% \mathrm{O}_{2}, 5 \% \mathrm{H}_{2} \mathrm{O}\right)$ 下, 光催化脱硝效率可达 $46 \%$. 提出了光催化脱硝反应机理.

关键词: 多壁碳纳米管; 二氧化钛; 光催化; 脱硝; 烟气

收稿日期: 2013-07-21. 接受日期: 2013-09-05. 出版日期: 2014-01-20.

*通讯联系人. 电话: (025) 85481132; 传真: (025) 85481273; 电子信箱: yanghongmin@njnu.edu.cn 基金来源：国家自然科学基金(50976049); 江苏省自然科学基金(BK2011788); 江苏省研究生科研创新计划(CXLX12-0410). 本文的英文电子版由Elsevier出版社在ScienceDirect上出版(http://www.sciencedirect.com/science/journal/18722067).

\section{1. 前言}

大气中 $\mathrm{NO}_{x}$ 主要源于燃煤电站以及机动车尾气的排 放, 是形成酸雨及光化学烟雾的诱因之一. NO排放的加 剧严重危害了生态环境及人类健康状况 ${ }^{[1,2]}$. 目前, 燃煤 电站氮氧化物脱除技术以选择性催化还原(SCR)及选择 性非催化还原 $(\mathrm{SNCR})$ 为主. SCR 具有较高的脱硝效率, 但存在投资成本较高及催化剂毒化等问题; 而SNCR无 需使用催化剂, 但温度窗口及反应时间等不易控制, 导 致脱硝效率较低 ${ }^{[3-5]}$. 作为一种新的大气污染控制技术, 以无毒无害的 $\mathrm{TiO}_{2}$ 为基础的光催化氧化法受到广泛的
关注 ${ }^{[6]}$. Wang等 ${ }^{[7]}$ 利用玻璃纤维负载 $\mathrm{TiO}_{2}$, 在固定床反 应器中进行 $\mathrm{NO}$ 的光催化氧化实验. 赵莉等 ${ }^{[8]}$ 利用石英 砂负载的 $\mathrm{TiO}_{2}$ 对 $\mathrm{NO}$ 进行光催化脱除. 在实际应用过程 中, $\mathrm{TiO}_{2}$ 存在禁带宽度大 $(3.2 \mathrm{eV})$ 及激发的空穴电子对在 迁移过程中易复合等缺点, 导致 $\mathrm{TiO}_{2}$ 光催化效率较低. 因此, 人们进一步对 $\mathrm{TiO}_{2}$ 进行改性, 以提高 $\mathrm{TiO}_{2}$ 的量子 收益及其在可见光区域的响应强度. Ananpattarachai 等 ${ }^{[9]}$ 利用溶胶凝胶法制备了 $\mathrm{N}$ 掺杂的 $\mathrm{TiO}_{2}$ 以及 $\mathrm{Li}$ 等 ${ }^{[10]}$ 利 用直接水解法制备了 $\mathrm{B}$ 掺杂的 $\mathrm{TiO}_{2}$, 结果表明, 利用离子 对 $\mathrm{TiO}_{2}$ 进行掺杂有效降低了禁带宽度. 李晓佩等 ${ }^{[11]}$ 测试 了酞菁改性的介孔 $\mathrm{TiO}_{2}$ 光催化性能, 结果表明, 染料敏 
化后光吸收边红移. 由于多壁碳纳米管(MWCNTs)具有 优异的机械性能、导电性、热力学性能及磁性, 人们对 $\mathrm{MWCNTs} / \mathrm{TiO}_{2}$ 开展了广泛的研究工作 ${ }^{[12]}$. Wang 等 ${ }^{[13]}$ 采 用溶胶凝胶法制备的 $M W C N T s-\mathrm{TiO}_{2}$ 进行了光降解苯酚 的研究. 杨汉培等 ${ }^{[14]}$ 采用水热法制备了 $\mathrm{CNTs}^{-} \mathrm{TiO}_{2}$, 并 考察其光催化降解甲基橙溶液的能力. 目前有关 MWCNTs/ $/ \mathrm{TiO}_{2}$ 的研究主要集中于光催化剂物理化学性 质及催化反应机理, 但应用只局限于液相条件下的苯酚, 甲基橙等, 有关气相污染物尤其是燃煤烟气中 $\mathrm{NO}$ 的光 催化脱除还鲜见报道.

本文采用溶胶凝胶法制备了 $\mathrm{MWCNTs} / \mathrm{TiO}_{2}$ 复合型 光催化剂, 利用透射电镜 (TEM), $X$ 射线光电子能谱 (XPS), X 射线衍射 (XRD) 及紫外 - 可见漫反射光谱 (UV-Vis) 对其进行理化表征; 以模拟燃煤烟气的 NO作 为目标污染物, 在固定床反应器中对 $\mathrm{MWCNTs} / \mathrm{TiO}_{2}$ 的 光催化脱硝性能进行评价, 研究了烟气组分浓度以及 MWCNTs的引入对 MWCNTs $/ \mathrm{TiO}_{2}$ 光催化脱硝效率的影 响.

\section{2. 实验部分}

\subsection{MWCNTs/ $/ \mathrm{TiO}_{2}$ 的制备}

MWCNTs购于中国科学院成都有机化学公司(纯 度 $>95 \%$, 直径 10-20 nm, 长度 10-30 $\mu \mathrm{m})$. 利用混酸法 对MWCNTs进行酸化处理, 将 $1 \mathrm{~g}$ MWCNTs超声分散于 $20 \mathrm{~mL}$ 浓盐酸及浓硝酸(南京化学试剂有限公司)的混合 溶液 $\left(\mathrm{H}_{2} \mathrm{SO}_{4}: \mathrm{HNO}_{3}=3: 1\right.$, 体积比), 并用去离子水反复冲 洗直至为中性, 置于 $80^{\circ} \mathrm{C}$ 的干燥箱中干燥 $12 \mathrm{~h}$.

将适量酸处理后的MWCNTs超声分散于 $75 \mathrm{~mL}$ 无 水乙醇( $\mathrm{AR}$, 南京化学试剂有限公司), $25 \mathrm{~mL}$ 钛酸四丁酯 (AR, 南京化学试剂有限公司)及 $4 \mathrm{~mL}$ 硝酸的溶液中, 置 于磁力搅拌器上持续摚拌, 形成悬浮液. 摚拌 $1 \mathrm{~h}$ 后, 将 5 $\mathrm{mL}$ 蒸馏水加入 $25 \mathrm{~mL}$ 无水乙醇中, 并调节 $\mathrm{pH}$ 至 2 , 形成混 合液. 将混合液逐滴加入悬浮液中, 陈化凝胶, $80^{\circ} \mathrm{C}$ 干 燥后, 在350-650 ${ }^{\circ} \mathrm{C}$ 空气中焙烧 $3 \mathrm{~h}$. 同上法制备对比样 品 $\mathrm{TiO}_{2}$, 只是不添加 MWCNTs. 在光催化脱硝实验中, 为了提高 $\mathrm{MWCNTs} / \mathrm{TiO}_{2}$ 与烟气的接触面积, 同时提高 光催化剂与烟气的接触时间, 对 $\mathrm{MWCNTs} / \mathrm{TiO}_{2}$ 进行涂 覆处理 ${ }^{[15]}$. 制备MWCNTs $/ \mathrm{TiO}_{2}$ 均匀的浆体, 将适量粒径 为 $2 \mathrm{~cm}$ 的颗粒状硅胶加入浆体中, 干燥后作为实验用光 催化剂颗粒.

\subsection{MWCNTs/ $/ \mathrm{TiO}_{2}$ 的表征}

未酸化及酸化处理的MWCNTs TEM照片采用日本
电子公司 $200 \mathrm{kV}$ 场发射透射电镜 $2100 \mathrm{~F}$ 型进行扫描分析, 测试前将样品超声分散于无水乙醇中, 高倍稀释后附着 于铜网(南京中镜科仪技术有限公司). 采用PHI Quantera II 型X射线光电子能谱仪对样品表面组成进行分析. 采用日本理学公司 D/max-2500/PC型阳极转靶X射线衍 射仪研究MWCNTs $/ \mathrm{TiO}_{2}$ 在不同焙烧温度下的晶相及结 晶度, 扫描速率为 $0.02^{\circ} / \mathrm{s}\left(5^{\circ}-85^{\circ}\right)$. $\mathrm{MWCNTs} / \mathrm{TiO}_{2}$ 的 UV-Vis光谱利用美国VARIAN公司的紫外/可见光分光 光度计进行测定.

\section{3. 催化剂的评价}

图1为实验系统原理图. 光催化实验在由 $60 \mathrm{~cm}$ 长的 双层石英管组成的固定床反应器中进行. 内外石英管的 直径分别为 28 和 $60 \mathrm{~mm}$. 内管用于放置波长为 $365 \mathrm{~nm}$ 的 高压录灯, 辐照强度为 $6.5 \mathrm{~W} / \mathrm{m}^{2}(125 \mathrm{~W}$, 上海季光特种照 明厂). 模拟烟气的成分为 $0-8 \% \mathrm{O}_{2}, 0-15 \% \mathrm{H}_{2} \mathrm{O}, 73-508$ $\mathrm{mg} / \mathrm{m}^{3} \mathrm{NO}, 155-1241 \mathrm{mg} / \mathrm{m}^{3} \mathrm{SO}_{2}$ 及平衡气 $\mathrm{N}_{2} . \mathrm{N}_{2}, \mathrm{O}_{2}$, $\mathrm{SO}_{2}$ 及 $\mathrm{NO}$ 均来自钢瓶气(南京特种气体有限公司), 通过 高精度质量流量计(北京汇博隆有限公司)调节各组分的 浓度. $\mathrm{N}_{2}$ 分为两路,一路与NO混合形成主反应气流. 另 一路与 $\mathrm{O}_{2}$ 结合进入水鼓泡器满足反应的湿度要求. 烟气 的总体积流量控制在 $2 \mathrm{~L} / \mathrm{min}$, 折合空速为 $250 \mathrm{~h}^{-1}$ ). 通过 在线测量ECOM烟气分析仪, 可以实时测定NO浓度. 制 备的光催化剂对 $\mathrm{NO}$ 有吸附作用, 在开启光源前持续通 入 $\mathrm{NO}$ 使得光催化剂达到吸附平衡, 以减少实验结果的 偏差. 在光催化脱硝实验中, 紫外光源开启后, 反应时间 控制在 $15 \mathrm{~min}$. 光催化剂的光催化能力以 $\mathrm{NO}$ 的脱除效 率进行衡量, $\mathrm{NO}$ 脱除效率的定义为 $R_{\mathrm{NO}}=\left[\left(\mathrm{NO}_{\text {in }}-\right.\right.$ $\left.\mathrm{NO}_{\text {out }} / \mathrm{NO}_{\text {in }}\right] \times 100 \%$, 其中 $\mathrm{NO}_{\text {in }}$ 为紫外灯开启前 $\mathrm{NO}$ 浓度; $\mathrm{NO}_{\text {out }}$ 为紫外灯关闭时 $\mathrm{NO}$ 浓度.

表1列出了光催化脱硝实验的条件. 工况1研究暗态 条件下 MWCNTs $/ \mathrm{TiO}_{2}$ 的吸附性能, 实验开始时, $\mathrm{NO}$ 首 先进入旁路, 浓度达到稳定后, 关闭旁路, NO进入光催 化反应器, 测量NO浓度的变化. 工况2研究UV单独光照 以及在硅胶, $\mathrm{TiO}_{2}$ 和 $\mathrm{MWCNTs} / \mathrm{TiO}_{2}$ 存在下相应的光催 化脱硝效率, 建立 $\mathrm{MWCNTs} / \mathrm{TiO}_{2}$ 的基准光催化脱硝效 率. 工况3-6研究烟气组分浓度对光催化脱硝效率的影 响. 脱硝实验中光催化剂使用量为 $25 \mathrm{~g}$.

\section{3. 结果与讨论}

\section{1. 光催化剂形貌}

图2(a)为MWCNTs的TEM照片 (分辨率 $100 \mathrm{~nm}$ ). 可 见, 未经酸化处理的MWCNTs发生了聚集, 表面存在部 
分无定形碳及其它的杂质, 长度较长, 直径为 $15-30 \mathrm{~nm}$. 图2(b)酸化处理后MWCNTs的TEM照片(分辨率 $20 \mathrm{~nm}$ ). 可以观测到MWCNTs 典型的中空结构. 酸化处理后 MWCNTs 末端开口, 即开端氧化, 同时MWCNTs发生折 断, 使得碳纳米管的长度变短; 管壁表面杂质明显减少. 图 2(c) 为 $\mathrm{MWCNTs} / \mathrm{TiO}_{2}$ 的 TEM 照片. 由图可见 MWCNTs 对 $\mathrm{TiO}_{2}$ 的负载, $\mathrm{TiO}_{2}$ 以簇状形式包裹在 MWCNTs管壁表面, 其外部直径大于 $20 \mathrm{~nm}$.

\section{2. $\mathrm{MWCNTs} / \mathrm{TiO}_{2}$ 晶型}

图3为 $500{ }^{\circ} \mathrm{C}$ 焙烧的 $\mathrm{TiO}_{2}$ 以及 350,500 和 $650{ }^{\circ} \mathrm{C}$ 焙烧 的 $\mathrm{MWCNTs} / \mathrm{TiO}_{2}$ 的 XRD 谱. 在 350 及 $500^{\circ} \mathrm{C}$ 焙烧时, $\mathrm{TiO}_{2}$ 以锐钛矿相为主, 在 $25.1^{\circ}(101)$ 面, $36.9^{\circ}$ (103)面, $37.6^{\circ}$ (004)面, $38.5^{\circ}$ (112)面, $47.9^{\circ}$ (200)面, 53. $8^{\circ}$ (105)面, $55.0^{\circ}(211)$ 面, $62.6^{\circ}$ (204) 面和 $75.1^{\circ}$ (215) 面分别检测出 不同程度的锐铁矿相 $\mathrm{TiO}_{2}$ 衍射峰. 焙烧温度为 $500{ }^{\circ} \mathrm{C}$ 时, $\mathrm{TiO}_{2}$ 的(101)面具有更窄的半高峰宽, 表明锐钛矿相结晶 度更高; 至 $650{ }^{\circ} \mathrm{C}$ 后, $\mathrm{TiO}_{2}$ 的晶型由锐钛矿相转变成金 红石, 对应的金红石的衍射峰 $\left(27.4^{\circ}\right)$ 明显增强. 利用分 析天平 (AUX320, 日本 SHIMADZU) 对 $650^{\circ} \mathrm{C}$ 焙烧的 $\mathrm{MWCNTs} / \mathrm{TiO}_{2}$ 进行精确称量, 发现与 $500{ }^{\circ} \mathrm{C}$ 焙烧的 $\mathrm{MWCNTs} / \mathrm{TiO}_{2}$ (其质量与制备时理论值相近)相比, 有明 显质量损失, 说明 $650^{\circ} \mathrm{C}$ 焙烧时MWCNTs 存在氧化损失. Li等 ${ }^{[16]}$ 在热重实验中也确认, MWCNTs 在 $550-750{ }^{\circ} \mathrm{C}$ 温 度区间有较大损失. 另外在XRD图谱中未检测出 $\mathrm{C}$ 的衍 射峰. Cong 等 ${ }^{[17]}$ 研究发现, MWCNTs 的衍射峰位于 $26.3^{\circ}$, 与锐钛矿 $(101)$ 面 $\left(25.3^{\circ}\right)$ 相近, 因而被遮蔽. 将 $500^{\circ} \mathrm{C}$ 焙烧的 $\mathrm{MWCNTs} / \mathrm{TiO}_{2}$ 的 XRD 谱在 $20^{\circ}-30^{\circ}$ 区 间 (图3插图)进行局部放大, 并未发现可能归于 $\mathrm{C}$ 的衍射肩 峰. 这主要是由于 MWCNTs含量较少且分布均匀. 另 外, 与 $500{ }^{\circ} \mathrm{C}$ 焙烧的纯 $\mathrm{TiO}_{2}$ 相比, 相同温度焙烧的 $\mathrm{MWCNTs} / \mathrm{TiO}_{2}$ 的(101)面衍射峰更加宽泛. 基于Scherrer 方程可以估算出 $\mathrm{MWCNTs} / \mathrm{TiO}_{2}$ 与 $\mathrm{TiO}_{2}$ 的晶粒尺寸分别 为 11 及 $19.1 \mathrm{~nm}$. 可见, MWCNTs的引入限制了 $\mathrm{TiO}_{2}$ 晶粒 的生长. TEM测得 $\mathrm{TiO}_{2}$ 平均粒径为 $15 \mathrm{~nm}$, 大于 $\mathrm{XRD}$ 估 算值. $L$ in 等 ${ }^{[18]}$ 发现XRD估算的为单晶粒径, 而 TEM测 试中, 晶粒会发生聚集, 单晶聚集成多晶, TEM测得的是 单晶及多晶粒径的平均值, 因而偏大. 下文光催化脱硝 实验中采用 $500{ }^{\circ} \mathrm{C}$ 焙烧的 $\mathrm{MWCNTs} / \mathrm{TiO}_{2}$.

\section{3. 表面化学成分分析}

图 4(a) 为 MWCNTs/ $\mathrm{TiO}_{2}$ 样品的XPS 宽扫图谱, 其 $\mathrm{C} 1 s, \mathrm{Ti} 2 p$ 及 $\mathrm{O} 1 s$ 的谱峰对应于 $\mathrm{C}, \mathrm{Ti}$ 和O元素. 图4(b)为 $\mathrm{MWCNTs} / \mathrm{TiO}_{2}$ 的C $1 s$ 窄扫图谱, 对其进行分峰拟合为三
个峰. $284.6 \mathrm{eV}$ 对应MWCNTs中典型的 $\mathrm{C}=\mathrm{C}$ 以及 $\mathrm{C}-\mathrm{C}$ 键; $285.9 \mathrm{eV}$ 对应 $\mathrm{C}-\mathrm{O}$ 键; $287.9 \mathrm{eV}$ 处的宽峰对应于 $\mathrm{C}=\mathrm{O}$ 键 ${ }^{[19]}$. 图 4(c) 为 $\mathrm{MWCNTs} / \mathrm{TiO}_{2}$ 的 $\mathrm{O} 1 s$ 谱, 解叠为 530.1, 531.1 和 $532.1 \mathrm{eV}$ 三个峰. 其中 $530.1 \mathrm{eV}$ 对应于晶格氧 (Ti-O键), $531.1 \mathrm{eV}$ 对应于样品表面羟基, $532.1 \mathrm{eV}$ 对应 于 $\mathrm{C}-\mathrm{O}$ 键 ${ }^{[17,19]}$. 从 $\mathrm{C} 1 s$ 谱中观测到的 $\mathrm{C}-\mathrm{O}$ 键以及 $\mathrm{O} 1 s$ 谱 中同时观测到的 Ti-O键和 $\mathrm{C}-\mathrm{O}$ 键, 可以确认 $\mathrm{Ti}-\mathrm{O}-\mathrm{C}$ 键的 存在. 图4(d) Ti $2 p$ 的谱中 Ti $2 p_{1 / 2}$ 及 Ti $2 p_{3 / 2}$ 结合能分别为 459.1 和 $465.4 \mathrm{eV}$, 可见 $\mathrm{Ti}^{4+}$ 为主要存在方式. 与纯 $\mathrm{TiO}_{2}$ 的 相比, $\mathrm{MWCNTs} / \mathrm{TiO}_{2}$ 的 Ti $2 p$ 结合能明显增大, 主要原因 为 MWCNTs 与 $\mathrm{TiO}_{2}$ 之间 $\mathrm{Ti}-\mathrm{O}-\mathrm{C}$ 键的存在而引发的电子 转移, 改变了 $\mathrm{Ti}$ 离子外部电子云的密度, 导致 Ti $2 p$ 结合 能的增加.

\section{4. 光催化剂光吸收性质}

图 5(a) 为 $\mathrm{MWCNTs} / \mathrm{TiO}_{2}$ 和 $\mathrm{TiO}_{2}$ 的 UV-Vis 谱. $\mathrm{TiO}_{2}$ 光吸收边在 $400 \mathrm{~nm}$ 附近, 在 400-800 nm区域光吸收较弱, 而 $\mathrm{MWCNTs} / \mathrm{TiO}_{2}$ 的光吸收边发生红移现象. 当 MWCNTs引入后, 它与 $\mathrm{TiO}_{2}$ 形成 $\mathrm{Ti}-\mathrm{O}-\mathrm{C}$ 键, 使得电子发 生转移, 从而导致了复合光催化剂的费米能级偏移 ${ }^{[20]}$. 另外, $\mathrm{MWCNTs} / \mathrm{TiO}_{2}$ 在可见光区域 $(400-800 \mathrm{~nm}$ )具有较 强的光吸收, 其原因可能为MWCNTs的电子迁移 $\pi \rightarrow \pi^{*}$ 及黑色的 $\mathrm{MWCNTs} / \mathrm{TiO}_{2}$ 在可见光区域具有一定的吸收 强度 ${ }^{[21]}$. 通过 $[F(R) h v]^{1 / 2}$ 对 $h v$ 做曲线 $(F(R)$ 为 KubelkaMunk 函数, $h$ 为普朗克常数, $v$ 为光频率) 对 MWCNTs/ $\mathrm{TiO}_{2}$ 和 $\mathrm{TiO}_{2}$ 的禁带宽度进行估算, 分别为 2.6 和 $3.0 \mathrm{eV}$ (图5(b)). 由此可见, MWCNTs的引入降低了 $\mathrm{TiO}_{2}$ 的禁带 宽度, 提高了 $\mathrm{MWCNTs} / \mathrm{TiO}_{2}$ 的光利用率.

\section{5. 光催化脱硝}

\subsection{1. 基准曲线}

图6为 $\mathrm{MWCNTs} / \mathrm{TiO}_{2}$ 上 $\mathrm{NO}$ 吸附性能. $\mathrm{NO}$ 在旁路达 到平衡后, 浓度稳定在 $189 \mathrm{mg} / \mathrm{m}^{3}$. 关闭旁路, 使烟气进 入光催化反应器, NO浓度迅速下降, 至 3 min时, 达最低, 为 $162 \mathrm{mg} / \mathrm{m}^{3}$. 随着涂覆型 $\mathrm{MWCNTs} / \mathrm{TiO}_{2}$ 的吸附饱和, $\mathrm{NO}$ 浓度逐渐回升, $18 \mathrm{~min}$ 时接近初始浓度. 可以看出, 涂覆型 $\mathrm{MWCNTs} / \mathrm{TiO}_{2}$ 对 $\mathrm{NO}$ 的吸附效率最高可达到 $14 \%$.

图7为紫外光照下不同催化剂上的光催化脱硝效率. 可以看出, 仅有紫外光照时, 光催化脱硝过程就可以发 生, $R_{\mathrm{NO}}$ 为 $16 \%$. 在紫外光照下 $\mathrm{NO}$ 的反应过程与光化学 烟雾产生的机理相似, $\mathrm{NO}$ 氧化形成的 $\mathrm{NO}_{2}$ 在紫外光照的 激发下发生光解形成强氧化性 $\mathrm{O}$, 进而 $\mathrm{O}$ 与 $\mathrm{O}_{2}$ 反应形成 强氧化性 $\mathrm{O}_{3}$. 强氧化性物质 $\mathrm{O}$ 及 $\mathrm{O}_{3}$ 的形成促进了 $\mathrm{NO}$ 的 
光化学氧化过程. 相关反应机理 ${ }^{[22]}$ 如下列反应式所示:

$$
\begin{aligned}
\mathrm{NO}_{2}+h v & \rightarrow \mathrm{NO}+\mathrm{O} \\
\mathrm{O}+\mathrm{O}_{2} & \rightarrow \mathrm{O}_{3}+\mathrm{O}+\mathrm{M} \\
\mathrm{O}_{3}+\mathrm{NO} & \rightarrow \mathrm{NO}_{2}+\mathrm{O}_{2} \\
\mathrm{O}+\mathrm{NO}+\mathrm{M} & \rightarrow \mathrm{NO}_{2}+\mathrm{M} \\
\mathrm{O}+\mathrm{NO}_{2}+\mathrm{M} & \rightarrow \mathrm{NO}_{3}+\mathrm{M} \\
\mathrm{O}_{3}+\mathrm{NO}_{2}+\mathrm{M} & \rightarrow \mathrm{NO}_{3}+\mathrm{O}_{2}+\mathrm{M}
\end{aligned}
$$

光催化脱硝实验中光催化剂堆积形式采用的是 $\mathrm{MWCNTs} / \mathrm{TiO}_{2}$ 涂覆硅胶, 以提高烟气与光催化剂接触 面积, 延长反应时间, 因此有必要探究硅胶颗粒单独存 在时对光催化脱硝过程的影响. 由图7可见, 在紫外光照 条件下, 硅胶颗粒的存在没有促进 $\mathrm{NO}$ 的脱除, $R_{\mathrm{NO}}$ 反而 有所下降. 硅胶具有一定的折射和反射作用, 降低了NO 接受 $\mathrm{UV}$ 的能量, 使得 $R_{\mathrm{NO}}$ 微降, 在光催化脱硝实验中硅 胶颗粒的影响可以忽略不计.

$\mathrm{MWCNTs} / \mathrm{TiO}_{2}$ 及 $\mathrm{TiO}_{2}$ 的 $R_{\mathrm{NO}}$ 分别为 $46 \%$ 和 $35 \%$, 明 显高于不含光催化剂时的 $R_{\mathrm{NO}}$. 与光化学 $\mathrm{NO}$ 脱除过程相 比, 光催化剂存在下的光催化脱除更有利. 光催化剂接 受的光子能量超过禁带宽度阀值, 可以形成大量的光生 空穴电子对. 空穴电子迁移至光催化剂表面后, 与 $\mathrm{O}_{2}$ 和 $\mathrm{H}_{2} \mathrm{O}$ 反应后会产生一系列的强氧化自由基 $\mathrm{O}_{2}{ }^{-}$和. $\mathrm{OH}$ 等, 从而使 $\mathrm{NO}$ 有效地被氧化, 氧化产物主要生成 $\mathrm{NO}_{2}, \mathrm{HNO}_{2}$ 和 $\mathrm{HNO}_{3}$. Devahasdin等 ${ }^{[23]}$ 认为, $\mathrm{NO}$ 的氧化产物的形成 是顺序发生的, 即 $\mathrm{NO} \rightarrow \mathrm{HNO}_{2} \rightarrow \mathrm{NO}_{2} \rightarrow \mathrm{HNO}_{3}$; 在反 应起始阶段, 产物以 $\mathrm{NO}_{2}$ 和 $\mathrm{HNO}_{2}$ 为主; 但反应进行到一 定阶段, 产物以 $\mathrm{HNO}_{3}$ 为主, 此时光催化剂表面呈酸性, 则会抑制 $\mathrm{HNO}_{2} \rightarrow \mathrm{HNO}_{3}$ 的反应过程. 主要的反应机理 [23,24] 总结如反应式(7)-(13):

$$
\begin{aligned}
\mathrm{TiO}_{2}+h v & \rightarrow \mathrm{e}^{-}+\mathrm{h}^{+} \\
\mathrm{h}^{+}+\mathrm{OH}^{-} & \rightarrow \cdot \mathrm{OH} \\
\mathrm{e}^{-}+\mathrm{O}_{2} & \rightarrow \mathrm{O}_{2}^{-} \\
\mathrm{NO}+\cdot \mathrm{OH} & \rightarrow \mathrm{HNO}_{2} \\
\mathrm{HNO}_{2}+\mathrm{OH} & \rightarrow \mathrm{NO}_{2} \\
\mathrm{NO}_{2}+\mathrm{OH} & \rightarrow \mathrm{NO}_{3}^{-} \\
\mathrm{NO}+\mathrm{O}_{2}^{-} & \rightarrow \mathrm{NO}_{3}^{-}
\end{aligned}
$$

\subsubsection{MWCNTs对光催化脱硝的影响}

由图 7 可见, $\mathrm{TiO}_{2}$ 为催化剂时 $R_{\mathrm{NO}}$ 仅为 $35 \%$, 而 $\mathrm{MWCNTs} / \mathrm{TiO}_{2}$ 的 $R_{\mathrm{NO}}$ 可达 $46 \%$, 其原因有三. 第一, MWCNTs 具有优异的导电性能, 可以作为电子快速传输 通道 ${ }^{[25,26]}$. $\mathrm{TiO}_{2}$ 具有有限的电子转移路径, 而MWCNTs 的存在为 $\mathrm{TiO}_{2}$ 提供了额外的电子迁移轨道, 即通过 Ti-O-C转移电子, 延长了电子空穴对的寿命. 第二, MWCNTs的引入抑制了 $\mathrm{TiO}_{2}$ 晶粒尺寸的生长. Devi 等 ${ }^{[27]}$ 研究表明, 光生空穴电子在迁移过程中的复合主要 可分为体复合和面复合, 其中以体复合为主. 具有较小 晶粒尺寸的光催化剂可以减少空穴电子迁移到表面的
时间, 减少体复合的几率. 第三, MWCNTs的引入使得 禁带宽度降低, 因而光利用率更高. 本文采用的紫外光 源是以 $365 \mathrm{~nm}$ 为主波长的紫外灯, 在400-800 nm区域也 有光强存在, MWCNTs $/ \mathrm{TiO}_{2}$ 禁带宽度的降低使得 $\mathrm{MWCNTs} / \mathrm{TiO}_{2}$ 在相同的辐照强度下可以激发更多的空 穴及电子.

\subsection{3. 烟气组分对光催化脱硝的影响}

图8(a)为NO初始浓度对光催化脱硝效率的影响. 由 图可见, 随着 $\mathrm{NO}$ 浓度的增加, 光催化脱硝率从 $46 \%$ 逐渐 下降至 $21 \%$, 与Langmuir-Hinshelwood 反应动力学原理 相符合. 在低浓度 $\mathrm{NO}$ 的条件下, 反应为一级反应; 而高 浓度时, 反应为 0 级, 光催化效率趋于稳定 ${ }^{[7]}$. 燃煤电厂 烟气组分中会含有一定浓度的 $\mathrm{SO}_{2}$, 为了探究 $\mathrm{SO}_{2}$ 对 $\mathrm{NO}$ 脱除效率的影响, 将 $155-1241 \mathrm{mg} / \mathrm{m}^{3} \mathrm{SO}_{2}$ 注入反应系统. 如图 8(b)所示, 当 $155 \mathrm{mg} / \mathrm{m}^{3}$ 的 $\mathrm{SO}_{2}$ 进入反应系统后, $R_{\mathrm{NO}}$ 从 $46 \%$ 降至 $39 \%$; 至 $1241 \mathrm{mg} / \mathrm{m}^{3}$ 时, $R_{\mathrm{NO}}$ 进一步降至 $29 \%$. $\mathrm{Li}$ 等 ${ }^{[28]}$ 研究表明, $\mathrm{NO}$ 主要吸附于光催化剂表面的羟基 基团, 而羟基基团和晶格氧也作为 $\mathrm{SO}_{2}$ 的吸附位点 ${ }^{[29]}$. $\mathrm{NO}$ 和 $\mathrm{SO}_{2}$ 同时进入反应体系后, 对共同吸附位点羟基基 团的竞争吸附导致了 $R_{\mathrm{NO}}$ 的下降.

许多研究表明, $\mathrm{O}_{2}$ 和 $\mathrm{H}_{2} \mathrm{O}$ 对于光催化氧化过程有重 要影响. 图8(c)为 $\mathrm{O}_{2}$ 浓度对光催化脱硝效率的影响. 在 无 $\mathrm{O}_{2}$ 条件下, $R_{\mathrm{NO}}$ 仅为 $17 \%$; 当 $\mathrm{O}_{2}$ 浓度增加至 $8 \%, R_{\mathrm{NO}}$ 增 至 $46 \%$. 图 $8(\mathrm{~d})$ 为 $\mathrm{H}_{2} \mathrm{O}$ 浓度对光催化脱硝效率的影响. 在 $5 \% \mathrm{H}_{2} \mathrm{O}$ 的条件下 $R_{\mathrm{NO}}$ 达到最大值, 为 $46 \%$; 继续增加 $\mathrm{H}_{2} \mathrm{O}$ 浓度到 $15 \%, R_{\mathrm{NO}}$ 降至 $41 \%$. 结果表明, 适当提高 $\mathrm{H}_{2} \mathrm{O}$ 和 $\mathrm{O}_{2}$ 浓度会促进光催化脱硝过程. 从反应式(8)和(9)可以看 出, $\mathrm{O}_{2}$ 和 $\mathrm{H}_{2} \mathrm{O}$ 水解形成的着基分别与迁移至光催化剂表 面的光生电子和空穴结合, 形成强氧化性的 $\mathrm{O}_{2}{ }^{-}$和 $\cdot \mathrm{OH}$. $\mathrm{O}_{2}$ 及羟基基团在作为电子势阱捕获空穴电子的同时, 促 发了反应式(10)-(13), 使得光催化脱硝效率增大 ${ }^{[30]}$. 相 对于 $\mathrm{O}_{2}, \mathrm{H}_{2} \mathrm{O}$ 对光催化的影响更受关注. 与 $\mathrm{O}_{2}{ }^{-}$相比, $\cdot \mathrm{OH}$ 具有更强氧化性; 另一方面 $\mathrm{H}_{2} \mathrm{O}$ 对光催化过程具有抑制 和促进的双重影响. $\mathrm{H}_{2} \mathrm{O}$ 能在催化剂表面水解形成的羟

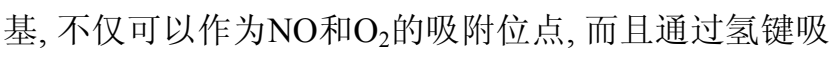
附更多的 $\mathrm{H}_{2} \mathrm{O}$, 进一步增加羟基基团数量 ${ }^{[31]}$, 提高光催 化脱硝效率. 赵莉等 ${ }^{[8]}$ 在研究 $\mathrm{TiO}_{2}$ 光催化脱硝过程时发 现, 当 $\mathrm{H}_{2} \mathrm{O}$ 含量大于 $6 \%$ 时, $\mathrm{H}_{2} \mathrm{O}$ 对光催化脱硝效率有抑 制作用, 但其并未给出原因. Henderson ${ }^{[32]}$ 研究表明, 光 催化剂表面形成的水层会抑制目标降解物进入吸附位 点或反应位点, 同样也会抑制 $\mathrm{O}_{2}$ 进入吸附位点, 从而阻 碍了光催化过程的进行. 本文结果表明, $\mathrm{H}_{2} \mathrm{O}$ 浓度为 
0-5\% 时, 高的 $\mathrm{H}_{2} \mathrm{O}$ 浓度有利于光催化脱硝, 而当 $\mathrm{H}_{2} \mathrm{O}$ 浓 度增至 $15 \%$ 时, $R_{\mathrm{NO}}$ 下降至 $41 \%$, 说明 $15 \% \mathrm{H}_{2} \mathrm{O}$ 在催化剂 表面形成水层, 抑制了分子扩散, 过量的 $\mathrm{H}_{2} \mathrm{O}$ 抑制光催化 脱硝. 在反应阶段, $\mathrm{H}_{2} \mathrm{O}$ 的重要性体现在对光催化产物 进行迁移, 抑制光催化剂的失活 ${ }^{[33,34]}$. $\mathrm{H}_{2} \mathrm{O}$ 促使处于吸 附位点吸附态的 $\mathrm{HNO}_{2}$ 及 $\mathrm{HNO}_{3}$ 转变为 $\mathrm{H}_{2} \mathrm{O}$ 中溶解态的 $\mathrm{HNO}_{2}$ 及 $\mathrm{HNO}_{3}$, 吸附态光催化产物的解吸过程实现了光 催化剂表面的自清洁, 避免了反应产物对吸附位点的堵 塞, 一定程度上抑制了光催化剂的失活.

\section{4. 结论}

采用溶胶凝胶法制备了 $\mathrm{MWCNTs} / \mathrm{TiO}_{2}$. MWCNTs
的引入优化了 $\mathrm{TiO}_{2}$ 的物理及化学结构. MWCNTs/ $\mathrm{TiO}_{2}$ 较小的晶粒尺寸, 降低了空穴电子体复合几率. 另一方 面, 额外的电子转移通道促使光生电子的快速转移, 促 进了空穴电子对的分离. 因而, 与纯 $\mathrm{TiO}_{2}$ 相比, $\mathrm{MWCNTs} / \mathrm{TiO}_{2}$ 表现出较好的脱硝性能. 光催化脱硝实 验中, 在最佳实验条件 $\left(73 \mathrm{mg} / \mathrm{m}^{3} \mathrm{NO}, 8 \% \mathrm{O}_{2}, 5 \% \mathrm{H}_{2} \mathrm{O}\right)$ 下, 光催化脱硝效率可达 $46 \%$. 较低的NO初始浓度有助 于 $\mathrm{NO}$ 的脱除. 另外, $\mathrm{SO}_{2}$ 存在降低了 $R_{\mathrm{NO}}$, 原因主要为 $\mathrm{NO}$ 和 $\mathrm{SO}_{2}$ 对表面有限的吸附及反应位点的竞争吸附; 由于 $\mathrm{H}_{2} \mathrm{O}$ 和 $\mathrm{O}_{2}$ 能够形成强氧化自由基 $\mathrm{O}_{2}{ }^{-}$和. $\mathrm{OH}$, 因而对光催 化脱硝有促进作用. 而过量 $\mathrm{H}_{2} \mathrm{O}$ 在催化剂表面形成水层 抑制光催化脱硝, 实验中 $15 \% \mathrm{H}_{2} \mathrm{O}$ 促使 $R_{\mathrm{NO}}$ 降低. 